\title{
ВЫПЛАТА РАБОТОДАТЕЛЕМ ЗАДЕРЖАННОЙ ЗАРАБОТНОЙ ПЛАТЫ В ПОРЯДКЕ СТАТЬИ 142 ТРУДОВОГО КОДЕКСА РОССИЙСКОЙ ФЕДЕРАЦИИ
}

\author{
А. А. Евстегнеева \\ Московский гуманитарный университет
}

\begin{abstract}
Аннотация: В статье обсуждается вопрос о возможном внесении изменения в статью 142 Трудового кодекса Российской Федерации в части, касающейся установления обязанности работодателя: в первую очередь выплатить задержанную заработную плату, а после этого уведомлять работника о выходе на работу.

Текст доклада автора на Общероссийской (национальной) научной конференции «Моисеевские чтения. Культура и гуманитарные проблемы современной цивилизации», которая состоялась 4-5 марта 2020 г. в Московском гуманитарном университете.
\end{abstract}

Ключевые слова: трудовой договор; заработная плата; задержка выплаты; приостановление работы; право работника

\section{THE PAYMENT OF DELAYED SALARY BY THE EMPLOYER UNDER ARTICLE 142 OF THE LABOUR CODE OF THE RUSSIAN FEDERATION}

\author{
A. A. Yevstegneyeva \\ Moscow University for the Humanities
}

\begin{abstract}
The paper discusses the possibility of making amendments to article 142 of the Labour Code of the Russian Federation as regards the employer's responsibility - first to pay the delayed salary, and then to notify the employee of their attendance.

The text of the author's speech at the All-Russian (National) Scientific Conference "Moiseev's Readings. The Culture and Humanitarian Issues of Modern Civilisation", which was held at Moscow University for the Humanities on 4-5 March, 2020.
\end{abstract}

Keywords: employment contract; salary; delay in payment; suspension of work; employee rights

Актуальность настоящего доклада заключается в том, что ситуация с полной или частичной задержкой выплаты заработной платы на 15 дней и более является очень распространённой и, к сожалению, часто используемой работодателями. Конечно, бывают сложные экономические ситуации в организации, но из-за них не должны страдать работники, добросовестно выполняющие свою работу.

Проведя аналогию бюджета государства с бюджетом семьи, можно отметить, что семья работника из-за факта задержки заработной платы недополучает доходов в семейный бюджет, а в дальнейшем в случае увольнения работника и вовсе есть вероятность, что в худшем случае, в случае полной невыплаты заработной платы, вопрос может стоять и о сохранении такой семьи, поскольку нет возможности её прокормить до момента получения первой заработной платы на новом месте работы.

Цель настоящего доклада - сформулировать предложение о внесении изменения в статью 142 Трудового кодекса Российской Федерации о корректировке порядка регулирования данной категории отношений между сторонами трудового договора, а именно, сначала работодатель исполнит обязанность по выплате задержанной заработной плате, а лишь только после этого уведомит работника о выходе на работу. 
Задача настоящего доклада - изучить доктринальные позиции о порядке взаимоотношений между работником и работодателем в исследуемой ситуации.

Теоретические основы приостановления работником работы в случае невыплаты работодателем заработной платы на протяжении более чем 15 дней. На работника, как субъекта трудового права, право распространяется как в субъективном смысле («Я имею право»), так и в объективном смысле («Право меня защищает»). При этом, большинство работников не желают вступать в конфликт с работодателем и просто ждут выплаты заработной платы. И это оправданно с той точки зрения, если работнику возраст или опыт не позволяет найти иную работу. Однако же в случае, когда работник уверен в себе и обладает достаточными правовыми знаниями, он может воспользоваться правом приостановить работу, осуществив ряд действий, предусмотренный статьёй 142 Трудового кодекса Российской Федерации.

Исходя из содержания исследуемой статьи, мы выявили определённый порядок действий, который должен совершить работник, чтобы правомерно приостановить работу. В противном случае работник рискует быть привлечённым к ответственности вплоть до увольнения по инициативе работодателя.

3. Р. Гареева отмечает, что право работников на отказ от выполнения работы является мерой вынужденного характера, предусмотренной законом для цели стимулирования работодателя к исполнению обязанности по выплате работникам заработной платы в установленные сроки и в полном объеме. Это право предполагает устранение работодателем допущенного нарушения и выплату задержанной суммы. «Несмотря на то, что приостановление работ особая форма самозащиты работником своего права на своевременную выплату заработной платы, закон требует соблюдения работником установленного порядка реализации указанного субъективного права. Во-первых, принимая во внимание, что решение о приостановлении работ принимается работником самостоятельно, на нем лежит обязанность в письменной форме уведомить работодателя о приостановке выполнения трудовой функции. Законодатель не устанавливает сроков предупреждения, однако, учитывая значение термина “предупреждение”» (Гареева (2014: 135-136).

Итак, работнику следует сделать следующее:

1) установить, не относится ли данный работник к категории, которым запрещено приостанавливать работу;

2) на 16 день невыплаты заработной платы известить работодателя в письменной форме о том, что он приостанавливает работу по причине, связанной с задержкой со стороны работодателя выплаты заработной платы;

3) если работник после подачи письменного извещения работодателю покинул рабочее место, то дождаться от работодателя письменного уведомления от работодателя о готовности произвести выплату задержанной заработной платы;

4) на следующий день после получения такого письменного уведомления от работодателя, работник, покинувший рабочее место, обязан выйти на работу.

М. Стрыгина выделяет следующие основные признаки самозащиты:

1. Самозащита носит правоохранительный характер, то есть основанием ее возникновения является правонарушение;

2. Самозащита имеет характер одностороннего действия субъекта трудового правоотношения;

3. Самозащита как форма защиты позволяет применять способы защиты. 
Применение их является правом лица и происходит во внеюрисдикционном порядке;

4. В случае необоснованного применения способов защиты закон предусматривает возможность оспорить факт их применения в суде;

5. Самозащита реализуется в форме активного действия лица (Стрыгина, 2012: 60-61).

Заслуживающей внимание представляется позиция А. Б. Канунникова, А. А. Пастухова, С. А. Канунникова: «Работникам следует помнить, что в целях самозащиты они имеют право предлагать записать в условиях трудового договора, а также коллективного договора конкретный повышенный размер денежной компенсации за нарушение сроков выплаты заработной платы. Это может стать для работодателей сдерживающим условием как от задержек зарплаты, так и от желания нанять других работников на период приостановки работы» (Канунников, 2007: 53).

Не подвергая критике целесообразностьданной мысли, следует лишь отметить, что весьма сомнительной представляется нам ситуация, при которой работодатель, даже добросовестный, согласится на включение в трудовой договор такой позиции, хотя бы из экономических соображений.

Мы согласны с мнением Н. Г. Гладкова, который отметил, что «В настоящее время у ученых общепринятого определения самозащиты нет» (Гладков, 2013: 6). Таким образом, данный вопрос не определён. Учитывая данный факт, работник может совершить ошибку, когда будет принимать решение о реализации вышеназванного порядка действий, и будет уволен за прогул.

Таким образом, мы считаем, что такое письменное уведомление работника должно быть подано в форме заявления. Из содержания должно следовать, что планируется именно приостановление работы в порядке статьи 142 Трудового кодекса Российской Федерации именно по причине задержки выплаты заработной платы более 15 дней. Следует отметить, что подача целесообразна на 16 день после установленной в трудовом договоре даты выплаты заработной платы. Более того, такое заявление должно быть подано именно работодателю, из чего следует, что на этом заявлении должна стоять подпись и печать, например, сотрудника из отдела входящей корреспонденции. Если же отказывают в принятии заявления, то его можно направить, например, посредством «Почты России» заказным письмом с уведомлением о принятии, а также с оформлением описи вложения.

Н. Г. Гладков отметил очень важную с точки зрения автора настоящего доклада мысль: «... наличие готовности произвести выплату заработной платы ещё не означает реальную её выплату» (Гладков, 2013: 8). Далее названный автор рассуждает о том, будет ли произведена оплата времени приостановления работы.

Мы же предпримем попытку развить названную мысль по нижеследующим основаниям.

Если коллеги, последовав примеру работника, приостановившего работу, примут аналогичное решение, то может возникнуть ситуация, что выполнять их работу будет некому или среди оставшихся данная нагрузка будет перераспределена. Однако, в любом из перечисленных случаев работодатель не будет получать прибыль. А значит, он может пойти на любые способы, в том числе и на обман, чтобы только вернуть работников на рабочие места.

Таким образом, мы видим, что сам по себе факт уведомления работодателя не является гарантией фактической выплаты заработной платы. 
В этой связи наше предложение следующее.

Следует внести изменение в статью 142 Трудового кодекса Российской Федерации, дополнив её часть пятую абзацами первым, вторым следующего содержания:

«Работодатель, получивший от работника письменное уведомление о приостановлении работы в порядке, установленном настоящей статьёй, обязан в срок до 7 календарных дней выплатить работнику невыплаченную в срок заработную плату.

Работодатель после выплаты работнику заработную плату, указанную в абзаце первой настоящей части, направляет работнику письменное уведомление с реквизитами документа, подтверждающего выплату заработной платы, указанной в абзаце первом настоящей части, и требованием выйти на работу».

Мы считаем, что такое внесение изменения в данную статью поможет решить такую проблему трудового рынка как задержка выплаты заработной платы.

\section{СПИСОК ЛИТЕРАТУРЫ}

Гареева, 3. Р. (2014) К вопросу о приостановлении работ в виду невыплаты заработной платы // Правовое государство: теория и практика. № 2 (36). С. 134-137.

Гладков, Н.Г. (2013) Вопросы повышения эффективности самозащиты трудовых прав работников // Трудовое право в России и за рубежом. № 1. С. 6-9.

Канунников, А.Б., Пастухов, А.А., Канунников, С.А. (2007) Правовая культура самозащиты работниками трудовых прав // Трудовое право. № 2. С. 51-54.

Стрыгина, М. (2012) Самозащита интересов работников и работодателей // Кадровик. Трудовое право для кадровика. № 8. С. 60-63.

Дата поступления: 30.03.2020 г.

Евстегнеева Анна Александровна - студентка юридического факультета, кафедры гражданского процесса и социальных отраслей права Московского гуманитарного университета. Адрес: 111395 , Россия, г. Москва ул. Юности, 5. Тел.: +7 (905) 126-48-93. Эл. адрес: evstegneeva.2015@mail.ru

Yevstegneyeva Anna Aleksandrovna, Student, Faculty of Law, Department of Civil Procedure and Social Branches of Law, Moscow University for the Humanities. Postal address: 5, Yunosti, St., Moscow, Russian Federation, 111395. Tel.: +7 (905) 126-48-93. E-mail: evstegneeva.2015@mail.ru

\section{Для цитирования:}

Евстигнеева А. А. Выплата работодателем задержанной заработной платы в порядке статьи 142 Трудового кодекса Российской Федерации // Научные труды Московского гуманитарного университета. 2020. №3. C. 33-36. DOI: https://www.doi.org/10.17805/trudy.2020.3.6 